\title{
ARTICLES
}

\section{Paying Down the Care Deficit The Health Consequences for Grandmothers Caring for Grandchildren in a Mexican Migrant Community of Origin}

\author{
Mary Alice Scott \\ Department of Anthropology \\ New Mexico State University
}

\begin{abstract}
While significant research addresses global chains of care work from the perspective of female migrant workers engaged in low-paid, unstable domestic labor in "receiving" communities, little research has focused on those who substitute for migrant workers to provide care in communities of origin. This article addresses that gap by focusing on the health consequences of care work for grandmothers in southern Veracruz, Mexico who assume the primary responsibility for caring for their grandchildren when the parents migrate out of the community. Based in the literature on care work and transnational families, this ethnographically-based article argues that grandmothers suffer consequences for their own health in three ways. They must deduct from their own health care resources - including time and money - to provide for their grandchildren. They must concede to the exploitation of already ill bodies to engage in the physical care of children and the household. Finally, they must transfer energy for self-care to caring for others thereby exacerbating their own existing health issues in order to meet the physical and emotional needs of their grandchildren. The article calls for further research in this area that aims to develop solutions to the problem of "care substitution" in transnational families.
\end{abstract}

Keywords: Intergenerational relationships, family, migration, care, Mexico

\section{INTRODUCTION}

"When are you going to start having babies?" teased Sara $^{1}$ as we ate breakfast one morning in her house in Los Cañales, a small town in southern Veracruz, Mexico. I hedged, "I'll start thinking about it when I finish school." I was uncomfortable with the question because as we became better acquainted, Sara began to hint - subtly at first, and then directly - that she would be happy to travel to the United States to care for my children once I started a family. I could then help her husband find work and her children learn English while she took care of my children and house. There were benefits on all sides in her estimation. While certainly aware of the potential for exploitation in this kind of labor arrangement - Sara had worked in the informal labor sector of the tourist industry in a resort town in Mexico - she trusted that I would ensure at the very least less exploitative arrangements. For me, it was not quite so clear cut. My academic training in anthropology and women's studies included critical analysis of global care work chains, and I did not want to become part of those chains as an employer. I also recognized, however, that the imagined benefits of living and working in my house in the United States reflected the intense lack of resources that Sara and other families like hers experienced. In the United States, she imagined, her family would have steady income from both parents. Her children would go to school in a place where education makes a difference in the kinds of jobs a person can achieve. They would live in a house with consistent running water, heat, and air conditioning - among other things. Sara was certainly acting in the best interests of herself and her family, and her expectations that life would improve in the United States were not necessarily unrealistic.

My academic study, however, shows a darker side to this kind of arrangement. Rather than an individual, mutually beneficial relationship between anthropologist and research participant, Sara's suggestion points to one 
relationship within a system of exploitation in which immigrant women work for low wages and limited benefits in jobs rendered "unskilled" through a belief in women as "natural" care givers. These difficult personal interactions with Sara were likely part of what drew my attention to grandmothers' care work. In Sara's envisioned world, her children would accompany her as she traveled to another country to perform domestic work for white, middle-class women like me. The reality for many migrant workers, however, is that they go alone, leaving their children in the care of others - often grandmothers.

While extensive research interrogates the exploitative conditions for immigrant women engaged in domestic labor in the global North, it often only hints at the consequences of care work for those who remain in communities of origin. My discussion of the health consequences of care for the women who engage in this care work contributes to research that seeks a more complex understanding of global care work chains, in particular health consequences for aging women with prolonged burdens of care. Grandmothers' experiences shed light on some of the lesser-studied consequences of transnational migration. This article begins with an overview of the research setting and methods. It then situates the study in the literature on care work and transnational families, and finally incorporates case studies from research in Los Cañales to rethink care work in the context of transnational migration. As I explain in more detail below, I argue that focusing on "care deficits" that are left when women migrate and leave their children in communities of origin only offers a partial theorization of global chains of care work. Examining the practice of "care substitution" allows for a more complex reading of transnational migration and care, in this case elaborating the health consequences of such substitutions.

\section{SETting AND Methods}

Since approximately the year 2000, sugar-cane producers in Los Cañales have seen a steady decline in income, an issue that has left many with few options but to migrate for work. The majority seek employment in nearby cities or Gulf of Mexico oil rigs. In such cases, they often either move their entire families with them or travel between work and their homes in Los Cañales. Some, however, head to Mexican border towns like Ciudad Júarez and to the United States. In these cases, female migrants often leave their young children in Los Cañales. This incorporation of transnational migration as an economic strategy reflects the general increase in migration in the south-southeast region of Mexico until 2009. Between 1987 and $1992,8.8 \%$ of the migrant population originated from this region. Between 1997 and 2002, it increased to 12.9\% (Leite et al. 2009). The actual number of migrants from Los Cañales itself is difficult to determine, but it is common to see several houses on a block boarded up because an entire family has left, seeking work elsewhere. The current global economic crisis has significantly reduced international migration to the United States; such migration from Mexico alone decreased 27\% between 2007 and 2009 (INEGI 2009). However, the number of Mexicans living in the United States continues to increase (Leite et al. 2009), likely signifying an increase in length of stay for multiple reasons, such as increased border enforcement, repayment of increased debts incurred in crossing, or completion of financial goals made at the outset of migration (Massey and Riosmena 2010; Passel and Cohn 2009). Initial plans to remain in the US for a short period to earn money to build a house or start a business shift to longer term visions, as does the necessity for longer term care of young children in origin communities.

The data presented below were collected between 2007 and 2009 as part of a larger ethnographic study of gendered health and illness experiences that involved 72 women in Los Cañales (representing approximately 10\% of households) both with and without migrant family members. Data collection methods included participant observation in women's homes, in health clinics, at community events and meetings, and during transport to larger health care facilities outside of town and in-depth interviewing that included questions about household migration status and experience, household earnings and expenditures, personal and family member health issues and illness experiences, research participant involvement in household reproduction activities, and research participant social network resources. All research participants orally consented to participation using protocols approved by the University of Kentucky Institutional Review Board. In this article, I focus in particular on the illness experiences of grandmothers who are caught up in the flows of migration through their care work. My research shows that in Los Cañales, when their children migrate to the United States, grandmothers often become the primary caregivers of their grandchildren and experience health consequences as a result.

\section{TheOrIZING CARE Work: Gendered AND GeNERATIONAL PERSPECTIVES}

I follow Zimmerman and colleagues (2006: 3-4) in understanding care work as "the multifaceted labor that produces the daily living conditions that make basic human health and well-being possible." All people, at some 
point, have been and will be dependent upon the care of another person (Meyer et al. 2000; Tronto 1993). Therefore, many analyses of care work seek not to problematize the act of caring itself (Bubeck 2002), but rather to unmask the naturalization of care as women's work, particularly the work of women who are marginalized by race, class, and nationality (Feder and Kittay 2002) and to examine care work as a site of social reproduction of the labor force and the basis for maintenance of social and economic institutions (Litt and Zimmerman 2003; Zimmerman et al. 2006). Feminist studies of care work and reproductive labor have proliferated alongside the increasing feminization of (undocumented) labor migration and globalization (see for example Anderson 2000; Chang 2000; Hochschild 2000; Mills 2003; Parreñas 2001b; Romero 2002). Care work is a commodity that the wealthy can purchase cheaply in a labor market that relies heavily on immigrant women. While the shift to paid care work increases job opportunities in general for women, it also pushes them towards exploitative care work.

As Anderson (2000) has argued in detail, national immigration policies frequently lead to informalized, undocumented care labor. Women who perform such labor may, for example, be required to relinquish passports and other legal documentation to employers. They are then tied to those employers and whatever conditions of labor the employers impose for the duration of their residence in the country, unless they wish to risk the possibility of being deported. That they often perform care work for middle-class or wealthy white women highlights the ways in which globalized care chains further stratify people by gender, class, race, and nation (Feder and Kittay 2002; Zimmerman et al. 2006).

Women's labor migration in such situations often initiates the creation of transnational families - families that are spatially and temporally separated through migration (Hondagneu-Sotelo and Avila 1997) - where care becomes distributed across national boundaries (Baldassar et al. 2007; Boehm 2008; Dreby 2006; Parreñas 2001a, 2005; Raijman et al. 2003). Hochschild (2000) has argued that migrant women often leave "care deficits" in their home communities when they travel for employment in other countries. Many women have children or aging parents who require additional care. While some migrant women are able to fill those deficits by employing another woman to perform care work in their homes, many lack the resources to hire a caregiver and instead must rely on unpaid female family members (Meyer et al. 2000). Research on care work has focused more attention on migrant women than on those who fill the so-called "care deficits" migration leaves in its wake 2 . Research focused on the site of "care deficits," such as the following analysis, reveals that the concept of "care deficits" risks obscuring the care work activities of women who fill in these gaps. In fact, the care "gap" is in some sense fictional because female kin often immediately fill it.

To illuminate the process of filling the care gap, I suggest thinking in terms of "care substitutions" (to borrow from Erel 2002). In such substitutions, gendered divisions of labor remain intact, but there is a generational shift in responsibility for doing care work at home. Instead of providing local care for their children, migrant women provide care for middle-class women in other countries. Instead of receiving care as they age, grandmothers in migrant communities of origin provide care for young children. The consequences of care work substitution for grandmothers include the production and exacerbation of chronic illness, an issue that underscores the need to deconstruct and work against not only the naturalization of care work as women's work, but also the ways in which such naturalization burdens particular women in specific global contexts. In the following analysis of several case studies, I explain some of the health consequences of "care substitutions" involving aging (although still relatively young) grandmothers by examining how they (1) deduct from their own resources, (2) exploit their own bodies; and (3) transfer care from themselves to others in order to eliminate the "care deficits" that children of female migrants might otherwise experience.

\section{"I'M TOO OLD FOR THIS": DEDUCTING FROM Health Care Resources}

"I'm too old for this," ${ }^{3}$ said Patricia, age 55, sitting on the couch in a house filled with the cacophonous sounds of her four grandchildren. The five-room house was packed with gifts from Patricia's daughter Susana who was working in Ciudad Juárez and her son Emiliano who was working in the United States. The living room housed an entertainment center with a large TV, a DVD player, and a stereo; furniture including a small couch, two overstuffed chairs, a rocking chair, and a coffee table; and a motorcycle that Patricia recently bought with remittances from Emiliano. The motorcycle sat in one corner of the room underneath a hammock that Patricia often used to rock her youngest granddaughter Teresita to sleep. As the grandchildren loudly maneuvered through the living room and out the door, Patricia ran her hands down her face and sighed. She felt "acabada" - which could be interpreted as both "used up" and "finished" with caring for young children - but had limited alternatives and little 
support $^{4}$. Patricia's younger daughter Ofelia had recently developed complications of kidney disease. In addition to caring for Susana's two children, Patricia added the responsibility of taking care of Ofelia and her two children. Patricia's sister lived next door but was often working in a city several hours away. Although Patricia experienced a significant increase in material possessions through gifts from Susana and Emiliano, she, like other grandmothers in Los Cañales, also experienced an intensification of carework as she became the primary care giver for her four grandchildren and Ofelia.

Patricia often spoke of this caregiving as a burden, particularly because she saw herself as aging rapidly due to type 2 diabetes. I use Patricia's experience here to illustrate the ways that grandmothers frequently must deduct from their own health care resources in order to support the grandchildren in their care. Although in Patricia's and others' cases, the parents sent money for the grandchildren's expenses, it was often not enough. For example, Patricia's older granddaughter Eva had started kindergarten, and Susana (Eva's mother) pledged to cover educational expenses. However, she could not always estimate the costs accurately nor could she always send money when Patricia needed it:

There are things that [Susana] is not able to pay, and we help her. Like right now, what [Eva] takes to school, her food. What I have to put in, I put in. And it's daily... a juice, a packet of those things... about 10 pesos goes.

Patricia supplemented these frequent expenses - snacks for school or supplies for a specific school project - that Susana did not calculate in her remittances. To cover household expenses, including those of her granddaughters, Patricia sold homemade candies and other food items. Her husband had also recently acquired a job as a security guard, which paid less than what the family needed to move out of poverty, but did provide a more stable source of income than many families were able to obtain. Therefore, Patricia did usually cover extra expenses, but her responsibilities extended beyond financial support.

She frequently expressed the tension she felt in having to choose between her granddaughters' care and her personal, including health, needs. During one of our conversations, she said:

I told [my daughter] that she should come back ${ }^{5}$ because I am going to give back her daughters. Can't you see that I am worn out? ...because imagine, I have to raise them...to wash for them, cook for them, give them food to eat... And [my children] got married and made their lives. I stayed here with my old man, and it's as if I were recently married [raising children again]. And now in bad health.

Patricia understood herself to be "too old" to shoulder additional caregiving responsibilities, a perception that was highlighted by her deteriorating relationship with her husband (who she was convinced had a younger girlfriend because Patricia's age made her no longer attractive to him). She additionally recognized the connection between her additional caregiving responsibilities and the decline in her own health. One day she told me, broom in hand, that she was too exhausted to even sweep the floor. She sat down on the couch rubbing her knee to alleviate the pain that the doctor told her was a result of diabetes-related poor circulation. The accumulation of care work for four grandchildren and her ill daughter left her unable to get up from her chair.

However, Patricia did not feel that she had a choice in whether to take care of her grandchildren or not - her responsibility as a grandmother left her no other viable options. Day care centers existed where Susana worked in Ciudad Júarez, but they were expensive. Patricia additionally felt that placing the children in a day care center would constitute neglect because she did not trust the child care facilities in the city. She recounted a conversation with Susana:

She told me, 'Mom, will you take care of them for me?' And I told her yes. I can't force, I don't want her to put them in daycare... better with me, with their grandmother than there. They rob them from you.

Rather than place her grandchildren in the care of strangers, in a place about which she had heard frightening stories, she preferred to take care of her grandchildren herself.

Patricia's diabetes was worsening, though. The doctor had recently prescribed insulin; diet and exercise alone was no longer an option. This new treatment would add to the long list of medications she was taking for hypertension, high cholesterol, and asthma. Already, she took her medication only sporadically due to limited supplies in the free health clinic and her inability to pay for medications at private pharmacies, largely due to the additional expenses incurred in caring for her grandchildren. In order to get an appointment at the public health center, she would have to arrive at the clinic before five o'clock in the morning 
with four children in tow to wait in line for one of the few available daily appointments. There was no guarantee that she would get an appointment, nor that the medicine she needed to take would be available in the clinic pharmacy ${ }^{6}$. Therefore, she usually did not even try.

Patricia directly related her caregiving responsibilities to the deterioration of her own health and indirectly suggested that it was unjust for her to have these responsibilities at this point in her life. Yet, she did not refuse to take care of her grandchildren. Even further, she took in her adult daughter Ofelia, in spite of the fact that Ofelia's husband lived and worked in the community. In the context of gendered concepts of care, his responsibility was to provide economically for the family, not to assist in the daily work of home dialysis and childcare. Like other grandmothers in my research, Patricia felt she had no choice but to take care of her family even at the expense of her own health. On numerous occasions, she intimated that she was frightened of meeting the same fate as her mother, who suffered the amputation of her leg and later died due to diabetes-related complications. The pain in Patricia's knee reminded her daily of that potential for herself. Unable to limit her care giving responsibilities out of both love and duty, Patricia, like other grandmothers in this study, deducted from her own health care resources material, physical, and emotional - to invest them instead in her children and grandchildren.

\section{“Who Was I Waiting For?" EXPLOITING THE BODY OF THE CAREGIVER}

Tamara, age 44, was raising her granddaughter with significant difficulty. She, like other grandmothers, considered her advanced age (in comparison to the young age at which many women in the community become mothers) a factor in her frequent fatigue and inability to muster the energy that she could as a young mother of three. Tamara became the primary caregiver for her oneyear old granddaughter, Rosita, when her daughter and her son-in-law migrated to the city of Veracruz. Although they were within a day's trip from Los Cañales, they left Rosita in Tamara's care several days each week. Tamara woke up throughout the night to feed Rosita, change her diapers, or comfort her. The activities were similar to those of raising her own children when she was in her late teens and early twenties. However, the experience was more difficult. She recalled being able to take care of her own children while still having time to attend to other household duties as well as to relax at moments during the day. She would carry one child on her hip and allow the other to cling to her leg while she was cleaning up the house or preparing food. Then, she still had the energy to play with them when she was finished working. She didn't have the same energy to take care of her granddaughter. The lack of energy made her feel old even though she was only in her 40s.

Additionally, Tamara's husband had recently awoken, unable to move due to a temporary paralysis from a chronic back injury. He had experienced this paralysis before, and Tamara knew that this time would be no different. She would have to help him do everything. When he was sick, she told me, he was like a child himself. The caregiving responsibilities she had now not only for her granddaughter, but also for her husband, increased her fatigue, pain, and nervios ${ }^{7}$. When I visited her, she would regularly tell me that she could not even pick up her granddaughter because her back was hurting so badly. Tamara was not relieved of caregiving when she was in pain, unlike her husband who demanded attention and care when in pain.

Like Tamara, Jesica similarly dealt with pain that left her exhausted, but she had limited options for relieving herself of care work in order to address her own health issues. Jesica was 62 years old and lived about one kilometer from the center of town where health facilities were located. She lived with her husband, her son (who is deaf), and two of her grandchildren. Her husband had what doctors (according to Jesica) said was dementia. Her grandson had developmental disabilities. Jesica's two daughters were both migrants. They lived in the city of Veracruz during our interviews, but one previously worked in Canada for several years.

Without her daughters present in the household, Jesica shouldered the majority of the caregiving responsibilities, reflecting the gendered relations of care common for all the grandmothers in this study. Her husband's dementia required Jesica's constant vigilance and daily care. Jesica was often kept awake at night because he experienced insomnia, and in his confusion tried to leave the house. Due to his incontinence, she had to frequently wash his clothes by hand, as the family had no washing machine. She also had to assist him in getting dressed, eating, and going to the bathroom. Her grandson's developmental disabilities kept him out of school and in Jesica's care.

Jesica's health issues were intertwined with her extensive caregiving. She had experienced the sometimes debilitating pain in her leg for more than 30 years and, although it was reduced with treatment from herbalists and medicine from the Social Security clinic ${ }^{8}$, when she worked a large 
number of hours the pain returned. However, she could not rest. As she explained,

Well, before, yes, it hurt quite a lot because I couldn't walk. It was a sting, a suffering...I did my daily chores because it doesn't matter, well, who was I waiting for? ...and, like that many years I raised my children and I was sick...

Who could Jesica wait for given the gendered dynamics of care work that structure her daily lived experiences? That her son or her husband could be of assistance was in many ways inconceivable. Although her husband was likely physically and mentally unable to provide assistance due to his illness, Jesica never recalled him even before his illness - engaging in the daily care work that sometimes left her unable to walk. I often observed her son return from a day of work (which was sporadic) to sit down at the table waiting for Jesica to serve him a meal. He did, however, frequently run errands into town for Jesica, who could not walk or ride a bicycle such a distance. That Jesica consistently held the major burden of care work in the house reflects the normalization of this work as women's work.

In an ideal world, Jesica would like her daughters to return to Los Cañales. If they did, Jesica would not be burdened with such substantial labor. Her daughters could take on some of that burden for her. When Jesica's daughter was in Canada, she sent significant remittances, but even from Veracruz, she provided more economic support than she would be able from Los Cañales. Such support has allowed Jesica to own a refrigerator and to pay for her husband's medical bills. Therefore, while she enjoyed the economic support she received from her migrant daughters, she was also concerned that the distance (particularly if her daughter returned to Canada) precluded the kind of support that requires her daughters' physical presence. They would be unable to accompany her to her husband's health care appointments or to periodically relieve her duties around the house, for example.

Tamara's and Jesica's situations reveal how the normalization of care work as women's work leads to the exploitation of aging bodies in the context of migration. Their daughters, who would likely share the burden of care work in a different situation, had migrated, leaving Tamara and Jesica with sole responsibility. Both women felt that their older bodies could not do what they could when they were younger, but neither could count on assistance from men present in the household - whether husbands or sons. Their chronic pain issues, then, are not simply a manifestation of the aging process. They result from a particular positioning of grandmothers as care workers in migrant-sending families.

\section{"I Think A Lot": TRANSFERring CARE FROM SELF TO OTHER}

Many grandmothers experienced the exacerbation of illnesses due to caring for grandchildren when parents migrated out of the community as we saw in the cases above. Patricia, Tamara, and Jesica struggled to address their own health issues while also serving the needs of their grandchildren. While they also often transferred care from themselves to others, Alicia's situation most clearly represents the transfer of care I elaborate here. Alicia has, in many ways, abandoned her efforts to address her diabetes because her doctor has told her that she must focus on herself in order to improve her condition - something she feels that she cannot do because she must focus her mental energy on her migrant children and on her grandchildren. Alicia, age 57, lived with her husband Alonso, her youngest son (age 23, singleand unemployed) and her granddaughter Veronica, age 12. Her oldest son, Veronica's father, was working in the United States. When he first migrated, he took his wife and two daughters. After some time in the US, the couple thought that Veronica was being exposed to too many "negative influences" - pressures to drink alcohol and use drugs, to have sex, to exhibit bad behavior at home and at school, and to drop out of school. When her older sister confirmed their fears by becoming pregnant at age 16, their preoccupation with Veronica increased. They sent her to live in Los Cañales with Alicia and Alonso. At the time of my interviews with Alicia, Veronica's parents could not send sufficient money for Veronica's care. Her father was sick and unable to work. Her mother only earned enough to cover their basic expenses in the United States. Therefore, Alicia and Alonso were responsible for all the costs associated with their granddaughter's care.

Alicia and Alonso had long dealt with complications in securing regular household incomes. Alonso's severe knee pain kept him from working in his former profession as a bricklayer. He could now only sell snacks from a tricycle in front of the elementary school. Alicia contributed from time to time with the sale of chickens. Alicia and Alonso's economic situation was more difficult during school vacations - he couldn't work at all, and she had to seek out temporary work like washing clothes to make up the difference. 
Alicia also had advanced diabetes. When I asked her about her illness she said

I am not afraid of death. Do you know what I'm afraid of? Leaving my kids. I know they love me a lot, you know? They love us...they love both of us. But they think about me more because of this illness that I have. He, I'm not going to tell you that he is healthy. He is also sick, but it's a slower illness. In me, I feel that it is advancing very rapidly. And the doctor tells me that it is because I think so much... and that I have to take care of myself because my illness is advancing. Recently I lost more weight...Look how much weight I lost! I can't control it, I feel badly; like I get the shakes, I shiver...And it's because of that same illness, the sugar [diabetes], that's what the doctor has told me.

In that context, she also worries about providing for her family, including for Veronica. Without remittances from her son, Alicia and Alonso need to feed themselves as well as finance the education, nutrition, clothing, and food for their granddaughter.

Just before I arrived in Los Cañales, Veronica contracted dengue when, unfortunately, it was also a difficult time financially for Alicia and Alonso. Dengue arrives regularly with the rainy season when the reproduction of mosquitos in standing water facilitates its propagation. But the rains also brought difficulty to Alonso in selling his snacks at the elementary school. Fewer children went to school because mudslides often blocked several roads, and sometimes Alonso could not ride his tricycle through the mud of the unpaved streets in his neighborhood. His knee pain weakened him, and he was unable to push the tricycle through the mud. Alicia was preoccupied about providing for her family in these conditions. She needed cash to buy daily necessities. Even though she could get credit at the stores, she was aware that credit has limits. She needed to maintain control over the debt to be able to pay it back during the rainy season when sales were more limited. If Alicia felt pressure when she needed to buy basic household items at the store, it is perhaps obvious that her worry would be even greater when someone in the family was ill. When Veronica contracted dengue, Alicia and Alonso took her to the doctor, but the only medicine they could give her was acetaminophen and juice to drink. They had to monitor her constantly to ensure that she did not develop a more serious form of the disease, which is more common in older children like Veronica.

As Alicia and Alonso often had difficulty obtaining money for their basic needs, an illness like that of their granddaughter creates an even more delicate situation. When they were younger, they were in a better position to look for work. Now, in addition to being limited by age and chronic illness, they have financial responsibility for their granddaughter. The lack of money and the well-being of their dependents are preoccupations that became part of their daily lived experience. For Alicia, as I mentioned earlier, it had the grave effect of worsening her diabetes what makes her "think", said Alicia, would quickly bring her to death.

The migration of Alicia's son left a major burden of reproductive labor on Alicia and Alonso, who stayed in Los Cañales, and this is not an uncommon phenomenon. In fact, what permits migrants to stay in the United States in spite of having poorly paid jobs is, in part, that much of the reproductive labor and support of the family of the migrant happens in communities of origin. Even though migration did not produce Alicia's diabetes, it is evident that the situation in which she found herself resulted from the vulnerability that accompanies the migrant and his or her family members. Alicia's "thinking" emerged from the particular structure of undocumented migrant lives that shifts care onto grandmothers thereby exacerbating illness, diminishing well-being, and increasing the potential for early death.

\section{CONCLUSION}

The research presented here suggests that gendered and generational notions of care - who should give what kinds of care, and who is competent to provide that care - place strains on women who have to move beyond the roles they feel competent to fulfill, particularly in the context of poverty and labor migration. Establishing new roles (ones which they have no real option but to engage) creates worry, stress, and fear for their own well-being and that of their children and grandchildren.

This examination of how caregiving creates such stresses contributes to ongoing cross-disciplinary and cross-cultural discussions of the health implications of grandmother caregiving. For example, there is no clear consensus that caregiving itself necessarily increases poor health outcomes for grandmothers. Some studies have shown, for example, an increased risk for coronary heart disease (Lee et al. 2003) and increases in stress that contribute to greater health vulnerabilities (Cross et al. 2010); while others have shown no significant differences in health outcomes (Chen and Liu 2012). Still others demonstrate a positive effect on grandmothers' health and well-being, particularly in cases where children are old enough to 
provide assistance with household duties and where they provide emotional support (Alber 2004; Ice et al. 2008). However, the context and circumstance of caregiving does have an impact (Hughes et al. 2007; Ingstad 2004), a finding that supports the research presented here. Significantly for this discussion, studies have shown that when it is parents' difficult circumstances - including drug abuse, incarceration, serious physical or mental illness - that lead to custodial caregiving of grandchildren, the grandparents are more likely to experience negative consequences (Goodman and Silverstein 2002). In the cases described here, the circumstances frequently include not only the stresses of migration but also caring for grandchildren and other ill family members. The health consequences of the tensions that arise in the context of parental migration and increases in already significant burdens of care are at some times more obvious than at others; however, the consequences are real. The grandmothers' life experiences presented in this article show the ways in which the global process of "care substitution" to aging women who live in circumstances of poverty and chronic illness act to diminish their quality of life.

In order to minimally fulfill their responsibilities of care, grandmothers in Los Cañales must shift their resources including time and money - into caring for grandchildren rather than using those resources to address their own health issues. As we saw in Patricia's case, waiting in line for a doctor's appointment is nearly impossible because time does not allow both seeking health care and taking care of grandchildren. Additionally because remittances are variable, Patricia and other grandmothers have limited financial resources to purchase medication like insulin when supplies are not available in local free clinics. Instead of "taking care" of her diabetes, Patricia spends time with her grandchildren, buys their snacks for school, provides their meals, and maintains their health. She must, however, deduct from her own resources to do so.

Although the relationship of power between women and their migrant children is far more equal than that between migrant women and their domestic employers, "care substitution" still places grandmothers in a situation of exploitation. Tamara and Jesica exemplify this condition, although all the grandmothers experienced it to some degree. Both Tamara and Jesica lived with daily chronic pain that required rest and relaxation, not prolonged care labor. Given their responsibilities for their grandchildren and their husbands, neither had the luxury of rest. As I argued above, the normalization of care work as women's work contributes to this exploitation of ill bodies. In both cases, men were present in the household who could have contributed to the care labor required to satisfy the needs of the very young and the very ill, giving Tamara and Jesica time to rest, but they did not.

In all cases, women transferred self-care to care for others. Alicia is a particularly good example of the ways that such a transfer happens. Her preoccupation with her family - including both her migrant children and her grandchildren - led to a decline in her own health. Her doctor repeatedly emphasized the need to reduce stress so that she could better control her worsening case of diabetes. A combination of poverty, migration, and illness limited Alicia's ability to experience moments free of stress. In a particularly insightful analysis of the consequences of migration and care, Alicia argued that she would ultimately die because she "thinks too much."

In spite of, or perhaps because of, care substitution that normalizes women as always already appropriate caregivers, grandmothers sometimes felt that they were inadequate to the task of mothering because they were too old or too ill to take care of children. Grandmothers also judged themselves against a notion of motherhood that they were unable to fulfill. Migrant mothers could not fulfill it because of distance from their children. For grandmothers, it was fatigue, the potential for health crisis, and pain in particular that limited their abilities to take care of their grandchildren. This tension drew energy away from grandmothers' self-care, whether that be through preparing diets according to doctor recommendations, attending appointments in the health clinic, or simply getting adequate sleep.

However, grandmothers also resisted the idea of being inadequate mothers in multiple, although partial, ways. They pointed out their poor health conditions as unavoidable limitations to mothering and refused to blame themselves for their poor health. Fathers and grandfathers were complicit in the construction of inadequate mothering because they offered little if any assistance that might improve care and relieve grandmothers. Their resistance to fully accepting the consequences of care work as natural and unavoidable was only partial, and perhaps necessarily so, because such resistance did not lead to changes in the situation of care work. The lack of economic resources grandmothers and their families experienced left them little option but to send some family members away to work while others remained in the community to fill in for the absent laborers. Women's longstanding relationships with their husbands and other family members - in which women were consistently the primary caregivers - left little practical or strategic way for women to shift any 
responsibility for care work onto others. In light of the case studies presented here, I would argue we need further research about care substitutions in the context of global migrations in order to deepen our understanding of the situation of grandmothers like Patricia, Tamara, Jesica, and Alicia. It is my hope that this research can help direct us towards programs, policies, and other solutions that allow older women to live the lives that they had hoped they could.

\section{Acknowledgements}

Funding for this research was provided through an NSF DDIG grant ID\#0752896 and a Fulbright IIE grant. I would like to thank Miriam Chaiken and two anonymous reviewers for commenting on a previous draft of this article. Any errors and omissions are entirely my own.

\section{Notes}

1 Names of research participants and of the research community are pseudonyms.

2 There are important exceptions in studies focused on grandparents caring for grandchildren whose parents have died of AIDS (see for example Ice et al. 2008; Upton 2003).

3 All interviews were conducted in Spanish. English translations are by the author.

4 It should be noted that the narratives of suffering that I present in this article could be read as constructions of a gendered personhood defined and in some ways strengthened by suffering. Malkin (2004), for example, describes how Mexican migrant men use stories of suffering to enhance their own status as providers for their families. Stephen (2001) also argues that women in the Co-Madres movement in El Salvador strategically deployed their roles as suffering mothers to effect productive international political action. In my research, many women focused on narratives of suffering to the exclusion of other kinds of life stories. Women's lives are not wholly defined by suffering, and their narratives are strategic and partial presentations of lived experience (see Hunt 2000). However, these partial representations do have real consequences for grandmothers' health, which is my focus here.

5 Susana did, in fact, return to the community at about the time I completed my fieldwork. It was unclear whether she planned to stay or had only come for a visit.

6 Elsewhere, I have written in detail about the practical barriers to health care access for women in Los Cañales who rely on the public health facilities for care (Scott 2010).
7 Nervios in this context is a chronic illness often characterized by anxiety, headaches, and high blood pressure (Davis and Low 1989) brought on by continual life stresses (see Baer et al. 2003). Low (1989) and others (Doyal 1995; Jenkins 1996) have argued that this idiom of distress expresses confrontation with social, political, and economic exploitation and violence.

8 The clinic is part of the Instituto Mexicano del Seguro Social or IMSS which provides care in Los Cañales to cane growers both active and retired.

\section{References}

Alber, Erdmute

2004 Grandparents as Foster-Parents: Transformations in Foster Relations between Grandparents and Grandchildren in Northern Benin. Africa 74(1): 28-46.

Anderson, Bridget

2000 Doing the Dirty Work?: The Global Politics of Domestic Labour. London: Zed Books.

Baer, Roberta, Susan C. Weller, Javier Garcia de Alba Garcia, Mark Glazer, Robert Trotter, Lee Pachter, and Robert E. Klein 2003 A Cross-Cultural Approach to the Study of the Folk Illness Nervios. Culture, Medicine, and Psychiatry 27(3): 315-337.

Baldassar, Loretta, Cora Vellekoop Baldock, and Raelene Wilding

2007 Families Caring Across Borders: Migration, Aging and Transnational Caregiving. New York: PalgraveMacmillan. Boehm, Deborah A.

2008 "For My Children": Constructing Family and Navigating the State in the U.S.-Mexico Transnation. Anthropological Quarterly 81(4): 777-802.

Bubeck, Diemut Grace

2002 Justice and the Labor of Care. In The Subject of Care: Feminist Perspectives on Dependency. Eva Feder Kittay and Ellen K. Feder, eds. Pp. 160-185. Lanham, Massachusetts: Rowman \& Littlefield Publishers, Inc.

Chang, Grace

2000 Disposable Domestics: Immigrant Women Workers in the Global Economy. Cambridge, Massachusetts: South End Press.

Chen, Feinian and Guanya Liu

2012 The Health Implications of Grandparents Caring for Grandchildren in China. The Journals of Gerontology, Series B: Psychological Sciences and Social Sciences 67(1): 99-112.

Cross, Suzanne L., Angelique G. Day and Lisa G. Byers

2010 American Indian Grand Families: A Qualitative Study Conducted with Grandmothers and Grandfathers who Provide Sole Care for Their Grandchildren. Journal of Cross Cultural Gerontology 25: 371-383.

Davis, Dona L. and Setha M. Low, eds.

1989 Gender, Health, and Illness: The Case of Nerves. New York: Hemisphere Publishing Corporation.

Doyal, Lesley

1995 What Makes Women Sick: Gender and the Political Economy of Health. New Brunswick, New Jersey: Rutgers University Press. 
Dreby, Joanna

2006 Honor and Virtue: Mexican Parenting in the

Transnational Context. Gender \& Society 20(1): 32-59.

Erel, Umut

2002 Reconceptualizing Motherhood: Experiences of Migrant Women from Turkey Living Germany. In The Transnational Family: New European Frontiers and Global Networks. D.F. Bryceson and U. Vuorela, eds. Pp. 127-146. Oxford: Berg.

Feder, Ellen K. and Eva Feder Kittay

2002 Introduction. In The Subject of Care: Feminist Perspectives on Dependency. Ellen K. Feder and Eva Feder Kittay, eds. Pp. 1-12. Lanham, Massachusetts: Rowman \& Littlefield Publishers, Inc.

Goodman, Catherine and Merril Silverstein

2002 Grandmothers Raising Grandchildren: Family Structure and Well-Being in Culturally Diverse Families. The Gerontologist 42(5): 676-689.

Hochschild, Arlie

2000 The Nanny Chain. American Prospect 11(4).

Hondagneu-Sotelo, Pierette and Ernestine Avila

1997 "I'm Here, but I'm There": The Meanings of Latina

Transnational Motherhood. Gender and Society 11(5): 548571.

Hughes, Mary Elizabeth, Linda J. Waite, Tracey A. LaPierre, and

Ye Luo

2007 All in the Family: The Impact of Caring for

Grandchildren on Grandparents' Health. Journal of Gerontology: Social Sciences 62B(2): S108-S119.

Hunt, Linda M.

2000 Strategic Suffering: Illness Narratives as Social Empowerment among Mexican Cancer Patients. In Narrative and the Cultural Construction of Illness and Healing. Cheryl Mattingly and Linda C. Garro, eds. Pp. 88107. Berkeley: University of California Press.

Ice, Gillian H., Amy Zidron, and Elizabeth Juma

2008 Health and Health Perceptions Among Kenyan Grandparents. Journal of Cross Cultural Gerontology 23(2): 111-129.

Ingstad, Benedicte

2004 The Value of Grandchildren: Changing Relations between Generations in Botswana. Africa 74(1): 62-75.

Instituto Nacional de Estadística, Geografia, e Informatica

(INEGI)

2009 Información Sobre el Flujo Migratorio Internacional de México. Aguascalientes, Aguascalientes, Mexico.

Jenkins, Janis H.

1996 The Impress of Extremity: Women's Experience of Trauma and Political Violence. In Gender and Health: An International Perspective. Carolyn F. Sargent and Caroline B. Brettell, eds. Pp. 278-291. Upper Saddle River, New Jersey: Prentice Hall.

Lee, Sunmin, Graham Colditz, Lisa Berkman, and Ichiro

Kawachi

2003 Caregiving to Children and Grandchildren and Risk of Coronary Heart Disease in Women. American Journal of Public Health 93(11): 1939-1944.

Leite, Paula, Maria Adela Angoa, and Mauricio Rodríguez

2009 Emigración mexicana a Estados Unidos: balance de las últimas décadas. In Situación Demográfica de México. Pp. 103-123. Mexico: Consejo Nacional de Población.
Litt, Jacquelyn S. and Mary K. Zimmerman

2003 Global Perspectives on Gender and Carework: An Introduction. Gender and Society 17(2): 156-165.

Low, Setha M.

1989 Gender, Emotion, and Nervios in Urban Guatemala. In Gender, Health, and Illness: The Case of Nerves. Dona L. Davis and Setha M. Low, eds. Pp. 23-48. New York: Hemisphere Publishing Corporation.

Malkin, Victoria

2004 "We Go to Get Ahead": Gender and Status in Two Mexican Migrant Communities. Latin American Perspectives 31(5): 75-99.

Massey, Douglas S. and Fernando Riosmena

2010 Undocumented Migration from Latin America in an Era of Rising U.S. Enforcement. The Annals of the American Academy of Political and Social Science 630: 294-321.

Meyer, Madonna Harrington, Pam Herd, and Sonya Michel

2000 Introduction: The right to-or not to-care. In Carework: Gender, Class, and the Welfare State. Madonna Harrington Meyer, ed. Pp. 1-4. New York: Routledge.

Mills, Mary Beth

2003 Gender and Inequality in the Global Labor Force. Annual Review of Anthropology 32:41-62.

Parreñas, Rhacel Salazar

2001a Mothering From a Distance: Emotions, Gender, and Intergenerational Relations in Filipino Transnational Families. Feminist Studies 27(2): 361-390.

2001b Servants of Globalization: Women, Migration, and Domestic Work. Stanford: Stanford University Press.

2005 Children of Global Migration: Transnational Families and Gendered Woes. Stanford: Stanford University Press.

Passel, Jeffrey S. and D'Vera Cohn

2009 Mexican Immigrants: How Many Come? How Many Leave? Washington, DC: Pew Hispanic Center.

Raijman, Rebeca, Silvina Schammah-Gesser, and Adriana Kemp

2003 International Migration, Domestic Work, and Carework - Undocumented Latina Migrants in Israel. Gender and Society 17(5): 727-749.

Romero, Mary 2002 Maid in the U.S.A. New York: Routledge.

Scott, Mary Alice

2010 La Mujer Se Va Pa'bajo: Women's Health at the Intersections of Nationality, Class, and Gender. Ph.D. dissertation, Department of Anthropology, University of Kentucky.

Stephen, Lynn

2001 Gender, Citizenship, and the Politics of Identity. Latin American Perspectives 28(6): 54-69.

Tronto, Joan C.

1993 Moral Boundaries: A Political Argument for an Ethic of Care. New York: Routledge.

Upton, Rebecca L.

2003 "Women Have No Tribe": Connecting Carework, Gender, and Migration in an Era of HIV/AIDS in Botswana. Gender and Society 17(2): 314-322.

Zimmerman, Mary K., Jacquelyn S. Litt, and Christine E. Bose 2006 Global Dimensions of Gender and Carework. Stanford, California: Stanford University Press. 